\title{
Role of Betalains as Natural Antioxidant in Modulating Renal Disorders in $\gamma$-Irradiated Mice
}

\author{
M. M. Darwish, G. A. El-Tawil and H. Ms. Mekawy* \\ Radiation Biology and *Food Irradiation Res., Dept., \\ National Centre for Radiation Research and Technology \\ (NCRRT), P. O. Box; 29 Nasr City, Egypt.
}

\begin{abstract}
B ETALAINS are natural antioxidants extracted from red B beet (Beta vulgaris L.), prevent lipid oxidation and improve antioxidant defence system in the animal tissue.

This study investigates the protective role of betalains on $\gamma$-rays-induced renal disorders in mice. Thirty two mice were divided into four groups; the first (control group) received the vehicle only for 33 days (control), the second (betalains group) received betalains $(80 \mathrm{mg} / \mathrm{kg}$ body weight/day) for 33 days, the third (irradiated group) received the vehicle for 30 days before exposed to 4 Gy $\gamma$-rays (one shot) and for 3 days after irradiation and the last (protected group) received betalains for 30 days before $\gamma$-irradiation and for 3 days after irradiation.

Gamma-rays-provoked oxidative stresses in renal tissue were indicated by significant increases of thiobarbituric acid reactive substances (TBARs), carbonyl content (PC) and total nitrate/ nitrite (NOx) as well as an increase of plasma renal tubular and glomerular markers; urea $(\mathrm{Ur})$, creatinine $(\mathrm{Cr})$ and $\gamma$-glutamyl transferase $(\gamma-\mathrm{GT})$. In dissimilarity, $\gamma$-rays-induced significant decreases of renal reduced glutathione (GSH) level as well as peripheral blood indices; total red blood cells (RBC), haemoglobin $(\mathrm{Hb})$, platelets $(\mathrm{Pt})$ and total white blood cells (WBC) and renal enzymatic antioxidants; super oxide dismutase (SOD), catalase (CAT), glutathione peroxidase (GPx) and glutathione $S$-transferase (GST).

The results indicate that the administration of betalains protects against renal disorders in mice irradiated by $\gamma$-rays.
\end{abstract}

Keywords: Betalains, renal distress, $\gamma$-rays, mice.

Ionizing radiation induces free radicals production such as hydrogen, hydroxyl, singlet oxygen and peroxyl radicals, in a cascade pathway. This irradiation can lead to mortality in mammals, so it is important to protect biological systems from radiation-induced tissue damage (Rzeszowska-Wolny et al., 2009). 
Natural plant extracts such as echinacea purpurea, betalains and gymnema Sylvester leaves have been shown to protect cells and tissues against ionizing radiation without adverse reactions (Abouelella et al., 2007, El Gharras, 2012 and Sharma et al., 2009). Accordingly, such plant extracts could be used as an adjunct to conventional radiotherapy. Betalains, are water-soluble pigments with high antiradical capacity (Gandia-Herrero et al., 2010), which were isolated from red beet and possess antioxidant activity in vivo and in vitro (El Gharras, 2012 and Kanner et al., 2001). It inhibits lipid peroxidation and haeme-decomposition (Cai et al., 2003).

The present study was carried out to investigate whether betalains had modulating renal disorders in mice irradiated by $\gamma$-rays.

\section{Materials and Methods}

\section{Animals}

Male albino mice $(18 \pm 2 \mathrm{~g})$ were housed at $22-24{ }^{\circ} \mathrm{C}$ and $60-70 \%$ relative humidity in a $12 \mathrm{~h}$ light/12 h dark cycle. All mice were given normal diet and water ad libitum.

\section{Chemicals and irradiation}

Betalains (extracted from red beets) were purchased from Wuxi Talen Bioproduct Co., China. All another analytical chemicals were purchased from Sigma-Aldrich (St. Louis, USA).

Whole-body $\gamma$-irradiation was performed at National Centre for Radiation Research and Technology (NCRRT), Nasr City, Cairo, Egypt, using Gamma Cell-40 biological irradiator delivered at a radiation dose rate of $0.44 \mathrm{~Gy} / \mathrm{min}$.

\section{Experimental plan}

Control group received the vehicle for 33 days. Betalains group: Mice were orally given betalains (dissolved in $1 / 2 \mathrm{ml}$ of water) at a dose of $80 \mathrm{mg} / \mathrm{kg}$ body weight/ day for 33 days by stomach tube according to Lu et al. (2009). Irradiated group: Mice were received the vehicle for 30 days before exposed to 4 Gy $\gamma$-rays and for 3 days after irradiation. Protected group (betalains $+\gamma$-rays): Mice administered betalains dosage for 30 days before exposure to $\gamma$-irradiation and for 3 days after irradiation. Mice were decapitated $24 \mathrm{~h}$ at the end of the experimental time.

Egypt. J. Rad. Sci. Aplicc., Vol. 25, No. 1-2 (2012) 
Natural plant extracts such as echinacea purpurea, betalains and gymnema Sylvester leaves have been shown to protect cells and tissues against ionizing radiation without adverse reactions (Abouelella et al., 2007, El Gharras, 2012 and Sharma et al., 2009). Accordingly, such plant extracts could be used as an adjunct to conventional radiotherapy. Betalains, are water-soluble pigments with high antiradical capacity (Gandia-Herrero et al., 2010), which were isolated from red beet and possess antioxidant activity in vivo and in vitro (El Gharras, 2012 and Kanner et al., 2001). It inhibits lipid peroxidation and haeme-decomposition (Cai et al., 2003).

The present study was carried out to investigate whether betalains had modulating renal disorders in mice irradiated by $\gamma$-rays.

\section{Materials and Methods}

\section{Animals}

Male albino mice $(18 \pm 2 \mathrm{~g})$ were housed at $22-24{ }^{\circ} \mathrm{C}$ and $60-70 \%$ relative

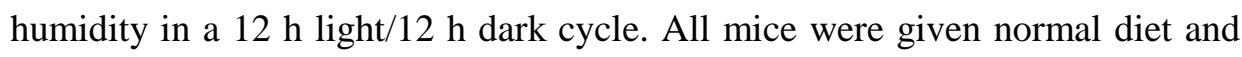
water ad libitum.

\section{Chemicals and irradiation}

Betalains (extracted from red beets) were purchased from Wuxi Talen Bioproduct Co., China. All another analytical chemicals were purchased from Sigma-Aldrich (St. Louis, USA).

Whole-body $\gamma$-irradiation was performed at National Centre for Radiation Research and Technology (NCRRT), Nasr City, Cairo, Egypt, using Gamma Cell-40 biological irradiator delivered at a radiation dose rate of $0.44 \mathrm{~Gy} / \mathrm{min}$.

\section{Experimental plan}

Control group received the vehicle for 33 days. Betalains group: Mice were orally given betalains (dissolved in $1 / 2 \mathrm{ml}$ of water) at a dose of $80 \mathrm{mg} / \mathrm{kg}$ body weight/ day for 33 days by stomach tube according to Lu et al. (2009). Irradiated group: Mice were received the vehicle for 30 days before exposed to 4 Gy $\gamma$-rays and for 3 days after irradiation. Protected group (betalains $+\gamma$-rays): Mice administered betalains dosage for 30 days before exposure to $\gamma$-irradiation and for 3 days after irradiation. Mice were decapitated $24 \mathrm{~h}$ at the end of the experimental time. 
Kidney organ was rapidly removed and washed in saline buffer and processed according to Varghese et al. (2009) for lipid peroxidation and antioxidant marker assays. Blood samples were prepared for blood indices by adding anticoagulant and for obtaining plasma by centrifugation at $1500 \mathrm{xg}$.

Renal lipid peroxidation (TBARs), PC, GSH and NOx estimations performed as renal oxidative stress parameters were assayed according to the procedures of Ohkawa et al. (1979), Levine et al. (1990), Hissin and Hilf (1973), and Miranda et al. (2001), respectively. Plasma levels of Ur, Cr and $\gamma$ GT were measured for assessment of the renal tubular and glomerular markers using method of Fawcett and Soctt (1960), Lustgarten and Wenk (1972) and Tietz (1994), respectively. Peripheral blood samples were analysed for total RBC, haemoglobin, platelets and total WBC were measured using Sysmex haematology analyser (model K4500, SYSMEX Shanghai Ltd., China). Determination of SOD, CAT, GPx and GST in kidney tissue were performed according to McCord (1985), Aebi (1984), Lawrence and Burk (1976) and Habig et al. (1974), respectively. Protein concentration was determined by the method of Bradford (1976).

Data are expressed as mean \pm S.E. of 8 mice per group. Statistical analysis was carried out using one way analysis of variance consider significant at $P<$ 0.05 followed by student's $t$-test (Snedecor and Cochran, 1994).

\section{Results}

Administration of betalains for betalains group of mice resulted in nonsignificant changes in all blood, plasma and renal biochemical's parameters, tested.

TABLE 1. Renal oxidative stress parameters; thiobarbituric acid reactive substances (TBARs), carbonyl content (PC), total nitrate/nitrite (NOx) and reduced glutathione (GSH) in different mouse groups.

\begin{tabular}{|c|c|c|c|c|}
\hline Mouse groups & $\begin{array}{c}\text { TBARs } \\
(\mu \mathrm{g} / \mathrm{g} \text { tissue })\end{array}$ & $\begin{array}{c}\text { PC } \\
(\mathrm{nmol} / \mathrm{mg} \text { protein })\end{array}$ & $\begin{array}{c}\text { NOx } \\
(\mathrm{nmol} / \mathrm{g} \text { tissue })\end{array}$ & $\begin{array}{c}\text { GSH } \\
(\mathrm{mg} / \mathrm{g} \text { tissue })\end{array}$ \\
\hline Control & $1.6 \pm 0.21^{\mathbf{a}}$ & $1.4 \pm 0.14^{\mathbf{a}}$ & $14.7 \pm 1.14^{\mathbf{a}}$ & $13.1 \pm 0.69^{\mathbf{a}}$ \\
\hline Betalains & $1.5 \pm 0.33^{\mathbf{a}}$ & $1.6 \pm 0.18^{\mathbf{a}}$ & $14.6 \pm 1.27^{\mathbf{a}}$ & $13.3 \pm 0.72^{\mathbf{a}}$ \\
\hline$\gamma$-rays $(4 \mathrm{~Gy})$ & $5.3 \pm 0.89^{\mathbf{b}}$ & $4.5 \pm 0.32^{\mathbf{b}}$ & $38.2 \pm 2.19^{\mathbf{b}}$ & $8.3 \pm 0.53^{\mathbf{b}}$ \\
\hline Protected & $2.1 \pm 0.16^{\mathbf{c}}$ & $2.1 \pm 0.26^{\mathbf{c}}$ & $16.6 \pm 1.35^{\mathbf{c}}$ & $11.1 \pm 0.82^{\mathbf{a}}$ \\
\hline
\end{tabular}

${ }^{a-c}$ Means in the same column with different superscript letters differ significantly at $P<0.05$.

Egypt. J. Rad. Sci. Aplicc., Vol. 25, No. 1-2 (2012) 
A significant increase in TBARs, PC and NOx levels accompanied by a significant decrease in GSH level in $\gamma$-rays group compared with control group, suggest kidney oxidative stress. However, administration of betalains normalise these parameters, Table 1. Plasma levels of Ur, $\mathrm{Cr}$ and $\gamma$-GT were increased significantly in $\gamma$-rays groups. Protected group treated with betalains significantly normalise the examined renal oxidative stress parameters, Table 2.

TABLE 2. Plasma renal tubular and glomerular markers; urea (Ur), creatinine $(\mathrm{Cr})$ and $\gamma$-glutamyl transferase $(\gamma$-GT) in different mouse groups.

\begin{tabular}{|c|c|c|c|}
\hline Mouse groups & $\begin{array}{c}\mathbf{U r} \\
(\mathrm{mmol} / \mathrm{L})\end{array}$ & $\begin{array}{c}\mathbf{C r} \\
(\mu \mathrm{mol} / \mathrm{L})\end{array}$ & $\begin{array}{c}\boldsymbol{\gamma} \text {-GT } \\
(\mathrm{U} / \mathrm{L})\end{array}$ \\
\hline Control & $1.43 \pm 0.245^{\mathrm{a}}$ & $0.65 \pm 0.391^{\mathrm{a}}$ & $0.71 \pm 0.132^{\mathrm{a}}$ \\
\hline Betalains & $1.41 \pm 0.256^{\mathrm{a}}$ & $0.62 \pm 0.414^{\mathrm{a}}$ & $0.72 \pm 0.214^{\mathrm{a}}$ \\
\hline$\gamma$-rays $(4 \mathrm{~Gy})$ & $3.88 \pm 0.543^{\mathbf{b}}$ & $1.23 \pm 0.232^{\mathbf{b}}$ & $2.84 \pm 0.227^{\mathbf{b}}$ \\
\hline Protected & $1.63 \pm 0.278^{\mathbf{c}}$ & $0.93 \pm 0.237^{\mathbf{c}}$ & $1.16 \pm 0.156^{\mathbf{c}}$ \\
\hline
\end{tabular}

Legends as in Table 1.

Compared with the control mice, the number of the RBC, WBC \& Pt and $\mathrm{Hb}$ concentration were significantly reduced. However, oral intake of betalains attenuated the radiation-induced reduction in red, white and Pt cells and in $\mathrm{Hb}$ level, suggesting that betalains confers radioprotection (Table 3).

TABLE 3. Peripheral blood indices; total red blood cells (RBC), haemoglobin (Hb), platelets (Pt) and total white blood cells (WBC) in different mouse groups.

\begin{tabular}{|c|c|c|c|c|}
\hline Mouse groups & $\begin{array}{c}\text { RBC } \\
\left(\mathrm{x} 10^{6} / \mu \mathrm{L}\right)\end{array}$ & $\begin{array}{c}\mathbf{H b} \\
(\mathrm{g} / \mathrm{dl})\end{array}$ & $\begin{array}{c}\mathbf{P t} \\
\left(\mathrm{x} 10^{4} / \mathrm{ml}\right)\end{array}$ & $\begin{array}{c}\mathbf{W B C} \\
\left(\mathrm{x} 10^{3} / \mu \mathrm{L}\right)\end{array}$ \\
\hline Control & $5.6 \pm 0.16^{\mathbf{a}}$ & $10.1 \pm 0.27^{\mathbf{a}}$ & $28.4 \pm 3.22^{\mathbf{a}}$ & $6.1 \pm 1.02^{\mathbf{a}}$ \\
\hline Betalains & $5.4 \pm 0.10^{\mathbf{a}}$ & $10.3 \pm 0.42^{\mathbf{a}}$ & $29.1 \pm 3.46^{\mathbf{a}}$ & $6.2 \pm 1.14^{\mathbf{a}}$ \\
\hline$\gamma$-rays $(4 \mathrm{~Gy})$ & $3.4 \pm 0.14^{\mathbf{b}}$ & $8.2 \pm 0.23^{\mathbf{b}}$ & $17.8 \pm 1.78^{\mathbf{b}}$ & $2.7 \pm 0.80^{\mathbf{b}}$ \\
\hline Protected & $5.1 \pm 0.12^{\mathbf{c}}$ & $9.2 \pm 0.21^{\mathbf{a}}$ & $24.3 \pm 2.63^{\mathbf{c}}$ & $5.8 \pm 1.35^{\mathbf{c}}$ \\
\hline
\end{tabular}

Legends as in Table 1.

TABLE 4. Renal enzymatic antioxidants; superoxide dismutase (SOD), catalase (CAT), glutathione peroxidase (GPx) and glutathione-S-transferase (GST) in different mouse groups.

\begin{tabular}{|c|c|c|c|c|}
\hline Mouse groups & $\begin{array}{c}\text { SOD } \\
(\mathrm{U} / \mathrm{mg} \text { protein })\end{array}$ & $\begin{array}{c}\text { CAT } \\
(\mathrm{U} / \mathrm{mg} \text { protein })\end{array}$ & $\begin{array}{c}\text { GPx } \\
(\mathrm{U} / \mathrm{mg} \text { protein })\end{array}$ & $\begin{array}{c}\text { GST } \\
(\mathrm{U} / \mathrm{mg} \text { protein })\end{array}$ \\
\hline Control & $90.3 \pm 7.42^{\mathbf{a}}$ & $33.4 \pm 2.31^{\mathbf{a}}$ & $345.6 \pm 34.33^{\mathbf{a}}$ & $6.2 \pm 0.46^{\mathbf{a}}$ \\
\hline Betalains & $88.5 \pm 8.03^{\mathbf{a}}$ & $31.7 \pm 2.62^{\mathbf{a}}$ & $314.3 \pm 31.24^{\mathbf{a}}$ & $6.1 \pm 0.38^{\mathbf{a}}$ \\
\hline $\boldsymbol{\gamma}$-rays $(4 \mathrm{~Gy})$ & $32.3 \pm 3.12^{\mathbf{b}}$ & $18.4 \pm 3.18^{\mathbf{b}}$ & $142.1 \pm 17.26^{\mathbf{b}}$ & $3.0 \pm 0.27^{\mathbf{b}}$ \\
\hline Protected & $79.6 \pm 6.21^{\mathbf{c}}$ & $27.9 \pm 2.11^{\mathbf{c}}$ & $278.5 \pm 18.44^{\mathbf{c}}$ & $5.1 \pm 0.21^{\mathbf{c}}$ \\
\hline
\end{tabular}

Legends as in Table 1.

Egypt. J. Rad. Sci. Aplicc., Vol. 25, No. 1-2 (2012) 
$\gamma$-irradiation significantly suppressed the enzymatic activity of SOD, CAT, GPx and GST in renal tissue. Oral administration of betalains partially restored the four enzymatic antioxidants activity, Table 4.

\section{Discussion}

Red beet root and leaf are consumed in salad with other vegetables worldwide. They are a good source of natural antioxidants such as, betalains, flavonoids, polyphenols, vitamins and folic acid (Lee et al., 2009); those act as reactive oxygen species (ROS) scavengers (Sepulveda-Jimenez et al., 2004). Betalains have been defined as condensation products of betalamic acid with different amines and amino acids (Gandia-Herrero et al., 2010); it has been appeared to be easily absorbed and detected in the urine of subjects who consumed red beet (Kanner et al., 2001).

In human and animal body, ROS can be neutralized by antioxidant compounds. However, excessive ROS production and the depleted antioxidant defences lead to oxidative stress and induce oxidative damage, causing pathological dysfunction in the organism (Urso and Clarkson, 2003). The consequences of these oxidative damage are multiple and invariably advice. They include lipid peroxidation, resulting in the destruction of membrane lipids, and oxidative DNA damage, collectively leading to the loss of cell viability, either via necrotic or apoptotic pathways (Marnett, 2000). Cells could be injured and even killed under the most serious conditions of radiation exposure, when the content of ROS get uncontrolled by the cellular antioxidants (Pathak et al., 2007).

In the present study, the significant increases in TBARs, PC and NOx levels in $\gamma$-rays group accompanied by a significant decrease in GSH level, suggest that oxidative stress occurs in kidney. Radiation-induced decline in GSH and augmentation in TBARs, PC and NOx levels in rats and mice tissues (Gharib and Fahim, 2007 and Sharma et al., 2009).

Betalains found to protect mice against the oxidative stresses-induced decline in GSH (Sunila and Kuttan, 2005) and enhancement in TBARs and PC (Reddy et al., 2005 and Tesoriere et al., 2004). The increase in GSH levels may be due to the activation of protective response in the kidneys to counteract the excessive formation of ROS. It acts as radical scavenger due to redox-active sulphydryl group directly reacting with oxidant and transforms itself into oxidised GSH (Pathak et al., 2007). These results suggest betalains from red beets are not only radio protective but are also effective as an antioxidant (Lu et al., 2009).

Egypt. J. Rad. Sci. Aplicc., Vol. 25, No. 1-2 (2012) 
Plasma levels of Ur, Cr and $\gamma$-GT were increased significantly in $\gamma$-irradiated mice due to impairment of kidney functions (El-Khafif et al., 2003). Treatment with betalains significantly normalise renal oxidative stress parameters. Betalains protect liver $\gamma$-GT (Schwartz et al., 1983) and improve renal function and excretion (Frank et al., 2005).

Gamma-rays irradiation induced a marked reduction in RBC, WBC, Pt counts and $\mathrm{Hb}$ concentration in mice due to direct destruction of the mature circulating cells and the damage effects on a large number of blood forming stem cells (Aboueldlla et al., 2007 and Tawfik et al., 2006). Betalains partially restored these values. Its protective effect against oxidative damage was evaluated in red and white blood indices of human and mice (Hari Kumar and Kuttan, 2004 and Tesoriere et al., 2006) and have a wide range of desirable biological activities, including antioxidant, anti-inflammatory and anti-cancer properties (Georgiev et al., 2010).

Gamma-irradiation significantly suppressed the enzymatic activity of SOD, CAT, GPx and GST in renal tissue. Cells produce antioxidants such as CAT, SOD, GPx and GST as a part of cellular defence system against ROS-mediated cellular injury (Rahman et al., 2006), that induced by ionizing radiation. Oral administration of betalains partially restored the four enzymatic antioxidants activity as reported in previous studies (Hari Kumar and Kuttan, 2004, Pradedova et al., 2010 and Sunila and Kuttan, 2005). Betalains are phytochemicals that were classified as antioxidants (Butera et al., 2002) suggest that they may behave as effective reducing species, whereas a clear antioxidant activity has been shown in biological environments such as membranes (Tesoriere et al., 2003).

\section{Conclusion}

Betalains supplementation could prevent lipid peroxidation and improve antioxidant defence system in the renal tissue and plasma of $\gamma$-irradiated mice.

\section{References}

Abouelella, A., Shahein, Y., Tawfik, S. and Zahran, A. M. (2007) Phyto therapeutic effects of Echinacea purpurea in gamma irradiated mice. J. Vet. Sci., 8, 341.

Aebi, H. (1984) Catalase in vitro. Methods Enzymol., 105, 121.

Bradford, M. M. (1976) A rapid and sensitive method for the quantitation of microgram quantities of protein utilizing the principle of protein-dye binding. Anal. Biochem., 72, 248.

Egypt. J. Rad. Sci. Aplicc., Vol. 25, No. 1-2 (2012) 
Butera, D., Tesoriere, L., Di Gaudio, F., Bongiorno, A., Allegra, M., Pintaudi, A. M., Kohen, R. and Livrea, M. (2002) Antioxidant activities of Sicilian prickly pear (Opuntia ficus indica) fruit extracts and reducing properties of its betalains: betanin and indicaxanthin. J. Agric. Food Chem., 50, 6895.

Cai, Y., Sun, M. and Corke, H. (2003) Antioxidant activity of betalains from plants of the Amaranthaceae. J. Agric. Food Chem., 51, 2288.

El Gharras, H. (2012) Betalain: a particular class of antioxidant pigment. Nat. Prod. Commun., 6, 1425.

El-Khafif, M., Ragab, M., El-Dawy, H. and Tawfik, S. (2003) Effect of taurine treatment on some biochemical parameters in gamma irradiated mice. Environ. Sci., 6, 393.

Fawcett, J. K. and Soctt, J. E., (1960) A rapid and precise method for the determination of urea. J. Clin. Pathol., 13, 156.

Frank, T., Stintzing, F., Carle, R., Bitsch, I., Quaas, D., Strass, G., Bitsch, R. and Netzel, M. (2005) Urinary pharmacokinetics of betalains following consumption of red beet juice in healthy humans. Pharmacol. Res., 52, 290.

Gandia-Herrero, F., Escribano, J. and Garcia-Carmona, F. (2010) Structural implications on color, fluorescence, and antiradical activity in betalains. Planta, 232, 449.

Georgiev, V., Weber, J., Kneschke, E., Denev, P., Bley, T. and Pavlov, A. (2010) Antioxidant activity and phenolic content of betalain extracts from intact plants and hairy root cultures of the red beetroot Beta vulgaris cv. Detroit dark red. Plant Foods Hum. Nutr., 65, 1105.

Gharib, O. and Fahim, Th. (2007) Antioxidant effect of chard plant on damages induced in rats after radiation exposure. Egypt. J. Rad. Sci. Applic., 20, 443.

Habig, W. Pabst, M. and Jakpoly, W. (1974) Glutathione transferase: a first enzymatic step in mercapturic acid formation. J. Biol. Chem., 249, 7130.

Hari Kumar, K. B. and Kuttan, R. (2004) Protective effect of an extract of Phyllanthus amarus against radiation-induced damage in mice. J. Radiat. Res., 45, 133.

Hissin, P. J. and Hilf, R. (1973) A fluorometric method for the determination of oxidized and reduced glutathione in tissues. Anal. Biochem., 74, 214.

Kanner, J., Harel, S. and Granit, R. (2001) Betalains - a new class of dietary cationized antioxodants. J. Agric. Food Chem., 49, 5178.

Lawrence, R. A. and Burk, R. F. (1976) Glutathione peroxidase activity in seleniumdeficient rat liver. Biochem. Biophys. Res. Commun., 71, 952.

Lee, J., Son, C., Kim, M., Kim, M., Kim, H., Kwak, E., Kim, S. and Kim, M. (2009) Red beet (Beta vulgaris L.) leaf supplementation improves antioxidant status in C57BL/6J mice fed high fat high cholesterol diet. Nutr. Res. Practice, 3, 114.

Egypt. J. Rad. Sci. Aplicc., Vol. 25, No. 1-2 (2012) 
Levine, R., Garland, D., Oliver, C., Amici, A., Climent, I., Lenz, A., Ahn, B., Shaltiel, S. and Stadtman, E. (1990) Determination of carbonyl content in oxidatively modified proteins. Methods Enzymol., 186, 464.

Lu, X., Wang, Y. and Zhang, Z. (2009) Radioprotective activity of betalains from red beets in mice exposed to gamma irradiation. Eur. J. Pharmacol., 615, 223.

Lustgarten, J. A. and Wenk, R. E. (1972) Simple, rapid, kinetic method for serum creatinine measurement. Clin. Chem., 18, 1419.

Marnett, L. J. (2000) Oxyradicals and DNA damage. Carcinogenesis, 21, 361.

McCord, J. M. (1985) Oxygen-derived free radicals in postischemic tissue injury. $N$. Engl. J. Med., 312, 159.

Miranda, K., Espey, M. and Wink, D. (2001) A rapid, simple spectrophotometric method for simultaneous detection of nitrate and nitrite. Nitric Oxide Biol. Chem., 5, 62 .

Ohkawa, H., Ohishi, N. and Yagi, K. (1979) Assay for lipid peroxides in animal tissues bythiobarbituric acid reaction. Anal. Biochem., 95, 351.

Pathak, C. M., Avti, P. K., Kumar, S., Khanduja, K. L. and Sharma, S. C. (2007) Whole body exposure to low-dose gamma radiation promotes kidney antioxidant status in Balb/c mice. J. Radiat. Res., 48, 113.

Pradedova, E. V., Tolpygina, O. A., Isheeva, O. D., Putilina, T. E. and Salyaev, R. K. (2010) Glutathione and glutathione-S-transferase activities of the vacuoles of the beet (Beta vulgaris L.) roots. Dokl. Biol. Sci., 433, 275.

Rahman, I., Biswas, S. and Kode, A. (2006) Oxidant and antioxidant balance in the airways and airway diseases. Eur. J. Pharmacol., 533, 222.

Reddy, M. K., Alexander-Lindo, R. L. and Nair, M. G. (2005) Relative inhibition of lipid peroxidation, cyclooxygenase enzymes, and human tumor cell proliferation by natural food colors. J. Agric. Food Chem., 53, 9268.

Rzeszowska-Wolny, J., Przybyszewski, W. M. and Widel, M. (2009) Ionizing radiation-induced bystander effects, potential targets for modulation of radiotherapy. Eur. J. Pharmacol., 625, 156.

Schwartz, S. J., von Elbe, J. H., Pariza, M. W., Goldsworthy, T. and Pitot, H. C. (1983) Inability of red beet betalain pigments to initiate or promote hepatocarcinogenesis. Food Chem. Toxicol., 21, 531.

Sepulveda-Jimenez, G., Rueda-Benítez, P., Porta, H. and Rocha-Soda, M. (2004) Betacyanin synthesis in red beet (Beta vulgaris) leaves induced by wounding and bacterial infiltration in preceded by an oxidative burst. Physiol. Mol. Plant Pathol., 64, 125.

Sharma, K., Singh, U., Vats, S., Priyadarsini, K., Bhatia, A. and Kamal, R. (2009) Evaluation of evidenced-based radioprotective efficacy of Gymnema sylvestre leaves in mice brain. J. Environ. Pathol. Toxicol. Oncol., 28, 311.

Egypt. J. Rad. Sci. Aplicc., Vol. 25, No. 1-2 (2012) 
Snedecore, G. W. and Cochron, W. G. (1994) Statistical Methods. $14^{\text {th }}$ ed. The Lowa State University Press, Ames, Lowa. USA.

Sunila, E.S. and Kuttan, G. (2005) Protective effect of Piper longum fruit ethanolic extract on radiation induced damages in mice. A preliminary study. Fitoterapia, 76, 649.

Tawfik, S. S., Abbady, M. I., Azab, Kh. Sh. and Zahran, A. M. (2006) Anticlastogenic and haemodynamic efficacy of flavonoid mixture challenging the oxidative stress induced by gamma rays in male mice. Egypt. J. Rad. Sci. Applic., 19, 73.

Tesoriere, L., Allegra, M., Butera, D., Gentile, C. and Livrea, M. A. (2006) Cytoprotective effects of the antioxidant phytochemical indicaxanthin in beta-thalassemia red blood cells. Free Radic. Res., 40, 753.

Tesoriere, L., Allegra, M., Butera, D. and Livrea, M. A. (2004) Absorption, excretion, and distribution of dietary antioxidant betalains in LDLs: potential health effects of betalains in humans. Am. J. Clin. Nutr., 80, 941.

Tesoriere, L., Butera, D., D’Arpa, D., Di Gaudio, F., Allegra, M., Gentile, C. and Livrea, M. A. (2003) Increased resistance to oxidation of betalain-enriched human low density lipoproteins. Free Radic. Res., 37, 689.

Tietz, N. W. (1994) Fundamentals of Clinical Chemistry, N.B. Saunders Co., Philadelphia, USA. p. 427.

Urso, M. L. and Clarkson, P. M. (2003) Oxidative stress, exercise, and antioxidant supplementation. Toxicology, 189, 41.

Varghese, J., Faith, M. and Jacob, M. (2009) Zinc prevents indomethacin-induced renal damage in rats by ameliorating oxidative stress and mitochondrial dysfunction. Eur. J. Pharmacol., 614, 114.

(Received: 10/12/2012;

accepted: 31/01/2013)

Egypt. J. Rad. Sci. Aplicc., Vol. 25, No. 1-2 (2012) 


\section{دور البيتالانس كمضاد للأكسدة طبيعي في الحد من اضطر ابات الكلي في

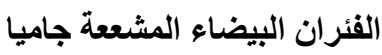 منال درويش ، و غادة أحمد الطويل ، و حسين محمد صلاح مكاوي

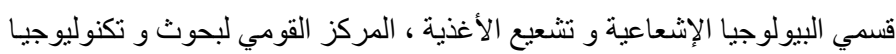

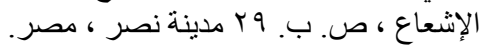

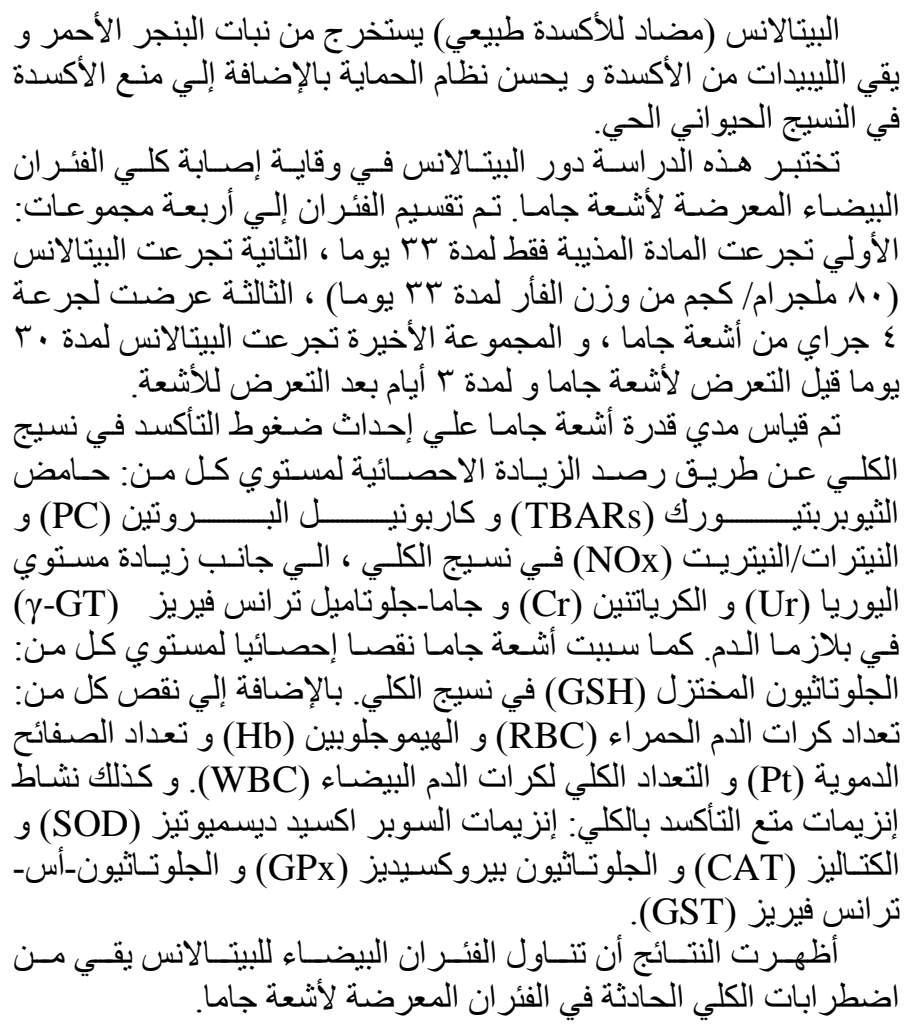

Egypt. J. Rad. Sci. Aplicc., Vol. 25, No. 1-2 (2012) 